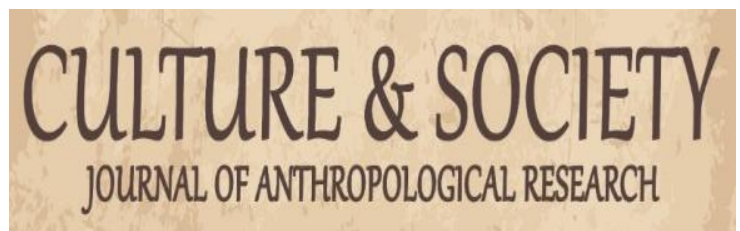

Culture \& Society: Journal of Anthropological Research

VOL. 1 NO. 1 SEPTEMBER 2019

http://culture.ppj.unp.ac.id

Email: culture@ppj.unp.ac.id

ISSN: 2686-343X (E-ISSN) 2686-3421 (P-ISSN)

DOI: https://doi.org/10.24036/culture/vol1-iss1/2

\title{
Jago Malam Dalam Rangkaian Upacara Sunatan Di Nagari Koto Tuo Kabupaten Tanah Datar
}

\author{
Feronika Daely ${ }^{1}$ Emizal Amri ${ }^{2}$ \\ ${ }^{1,2}$ Universitas Negeri Padang, Indonesia \\ Email: feronicadaely365@gmail.com,emizalamri@fis.unp.ac.id
}

\begin{abstract}
Abstrak
Penelitian ini bertujuan untuk menggali makna masyarakat Koto Tuo melakukan kegiatan Jago Malam setelah sunatan pada siang harinya dan bagaimana masyarakat setempat memandang kegiatan tersebut. Dilihat dari segi jenisnya, penelitian ini termasuk penelitian kualitatif dengan metode studi kasus. Pengumpulan data dilakukan melalui wawancara, observasi, dan studi dokumen. Analisa data yang dipakai adalah model analisa interaktif Miles dan Huberman. Hasil penelitian menunjukkan bahwa (1) Jago malam ialah suatu kegiatan dalam rangkaian upacara sunatan di nagari Koto Tuo. Kegiatan ini dilakukan sekali setahun tepatnya 29 Sya'ban dan kegiatan jago malam yang yang dimulai setelah anak dari tuan rumah sudah bersunat. Pada malam itu dilakukan permainan Koa maupun Remi, dalam beberapa kasus Jago Malam dimeriahkan berupa orgen tunggal maupun saluang; (2) Permainan Koa yang dilakukan secara kelompok selama Jago Malam disebut oleh warga setempat dengan Labuan. Jumlah pemain dalam satu labuan bisa berbeda tergantung jumlah pemain yang datang untuk bermain. Dalam satu labuan pemain bisa bermain individual atau berpasangan tergantung kesepakatan bersama. Seorang pemain dikatakan menang, jika sudah melewati tiga kali putaran atau tiga kali sampai oleh para pemain.
\end{abstract}

Kata kunci: Upacara Sunatan, Jago Malam, Masyarakat Koto Tuo

\section{Abstract}

This study aims to explore the meaning of the Koto Tuo community to carry out "Jago Malam" activities at night after circumcision and how local people view the "Jago Malam" activity. This type of research is qualitative research using a case study approach. Instrumern research uses interviews, observation, and documentation studies. Analysis of the data used is an interactive analysis model of Miles and Huberman. The results showed that (1) Jago Malam was one of the activities in a series of circumcision ceremonies in the Koto Tuo Nagari. This activity is carried out once a year 29 Sya'ban starting at night after the child of the host is circumcised. This activity will be accompanied by games of Koa and rummy, and night entertainment in the form of single or single organ participating in the series of good night activities; (2) Koa games performed in groups during Jago Malam are referred to by local residents with Labuan. The number of players in one copy can differ depending on the number of players who come to play. In one copy the player can play individually or pair depending on the mutual agreement. A player is said to win, if he has passed three rounds or three times up to the players.

Keywords: Circumcicion Ceremony, Jago Malam, Koto Tuo Community

Received: August 29, 2019 Revised: September 4, 2019 Published: September 6, 2019

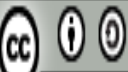




\section{Pendahuluan}

Kebudayaan adalah kompleks yang mencangkup, pengetahuan, kepercayaan, kesenian, moral, hukum, adat-istiadat, dan lain kemampuan serta kebiasaan oleh manusia anggota masyarakat. Tradisi adalah kebiasaan sosial yang diturunkan dari suatu generasi ke generasi lainnya melalui proses sosialisasi (Gibran, 2015). Tradisi sunatan merupakan sesuatu yang diwariskan secara turun temurun dari nenek moyang terdahulu baik dari hal kebiasaan maupun kepercayaan ("Pertunjukan Kesenian Pantun Rajah Grup Gentra Pusaka Panca Tunggal Dalam Acara Ngaruat Anak Tunggal Dalam Acara Ngarut Anak Tunggal di Lebak Mekar Kabupaten Cirebom," 2013). Jago malam merupakan salah satu tradisi masyarakat Minangkabau di Nagari Koto Tuo, Kabupaten Tanah Datar. Jago malam diadakan oleh masyarakat setempat dalam rangkaian upacara sunatan. Khitan bagi laki-laki adalah syarat wajib bagi kesucian karena tidak diterima sholat seseorang yang tidak disunat, baik laki-laki maupun perempuan (Sadalam, 1996). Masyarakat setempat mengadakan sunatan secara serentak dan hanya dilakukan sekali setahun, mulai 29 Sya'ban sampai dengan 10 syawal.

Kebiasaan masyarakat setempat mengadakan kegiatan jago malam merupakan salah satu rangkaian kegiatan oleh masyarakat Koto Tuo yang masih ada dan dilaksanakan. Tercatat dalam tiga tahun terakhir dari tahun 2017-2019 sudah terdata anak yang sunatan berjumlah 55 orang. Diantaranya pada tahun 2017 tercatat ada 15 anak, 2018 ada 15 anak dan 2019 tercatat ada 25 anak yang disunat dan mengikuti rangkaian upacara sunatan dari awal hingga akhir.

Sunatan pada masyarakat setempat, selalu diawali dengan upacara pembukaan secara serentak, tepatnya sehari sebelum bulan puasa. Upacara itu dinamakan oleh masyarakat setempat makan-makan. Rangkaian Upacara ini dilaksanakan dari pukul 07.00-11.00 WIB dan diawali dengan anak-anak yang akan disunat dikumpulkan di depan kantor KAN (Kerapatan Adat Nagari) sembari mendengarkan informasi dari Wali Nagari. Setelah dikumpulkan anak-anak akan diarak dari depan kantor KAN berjalan menuju daerah Bawah Kawek, Kampai, Piliang, Bendang, Caniago dan kembali ke depan kantor KAN. (Cahyono, 2006) Anak-anak dan warga setempat yang ikut dalam proses arak-arakan akan diiringi bunyi-bunyian alat musik tradisional "Talempong". Jumlah alat musik/instrumennya terdiri dari lima sampai enam buah talempong yang dimainkan oleh para tetua di Nagari Koto Tuo. Dalam bahasa lain yang identik (Minangkabau) yaitu bunyi Limo Salabuan atau bunyi Onam Salabuan (Editor,.). Anak yang akan disunat berpakaian adat Minangkabau yang memiliki cirikhas harus memakai "GANTO" (Gelang Kaki yang berbunyi).

Setelah arak-arakan selesai, pelaksanaan sunatan akan dimulai. Hanya saja anak-anak itu disunat di waktu dan tempat berbeda-beda, tergantung pada pilihan keluarga anak yang akan disunat. Dalam realitanya anak bisa langsung disunat segera setelah arak-arakan, tetapi ada juga yang melaksanakannya setelah lebaran. Rangkaian upacara sunatan itu terdiri dari arak-arakan, sunatan dan pada malam hari setelah sunatan diadakannya hiburan malam. Hiburan malam ini dinamakan oleh masyarakat setempat dengan Jago Malam. Hiburan malam menjadi daya tarik bagi warga Koto Tuo, karena dalam mengisi rangkaian kegiatan sebelum ada permainan Koa dan Remi ataupun orgen tunggal atau saluang (Panjaitan \& Bayu, 2018).

Fenomena ini menarik diteliti karena pertama, jago malam itu difasilitasi oleh tuan rumah dengan mengadakan permainan berupa kartu remi dan kartu koa. Permainan ini dimulai sekitar jam 23.00 sampai selesai lazimnya sampai pukul $03.00 \mathrm{WIB}$, tergantung kesepakatan para pemain. Warga yang datang dan ingin bermain mereka akan bermain di dalam rumah anak yang sunat, dan ada juga yang dilaksanakan di halaman rumah, tergantung berapa banyak warga yang datang dan tuan rumah menyediakan fasilitas untuk bermain. Jika hanya satu atau dua Labuan warga yang datang, maka mereka biasanya bermain di dalam rumah saja. Jika delapan pemain yang datang dan ingin bermain remi maupun koa, maka pemain akan dibagi menjadi dua kelompok, kelompok itu disebut sebagai "Labuan" oleh masyarakat setempat. Dalam labuan itu minimal ada tiga orang pemain dan maksimal enam orang pemain. Sebelum diadakannya kegiatan Jago Malam ini, tuan rumah terlebih dahulu melaksanakan syukuran di rumahnya. Itu bisa setelah anaknya selesai sunat dan bisa juga pada malam harinya sebelum diadakannya kegiatan permainan remi

\section{Culture \& Society: Journal of Anthropological Research Vol. 1, No. 1, Th. 2019}


maupun koa. Ketika acara syukuran sudah selesai, maka kegiatan Jago Malam sudah bisa dimulai, tuan rumah akan menyediakan fasilitas permainan berupa kartu remi maupun kartu koa. Para pemain akan mengunjungi dan bermain di dalam rumah anak yang sunatan.

Masyarakat yang anaknya ikut disunat juga akan menyediakan hiburan orgen tunggal atau "saluang", agar banyak warga berkunjung ke rumahnya untuk bajago malam. Jika mengadakan acara bajago malam secara besar-besaran, maka akan banyak pula fasilitas permainan yang harus disediakan tuan rumah, dan permaianan akan berlangsung sampai ke halaman rumah tersebut. Tuan rumah menyediakan meja dan fasilitas untuk bermain lainnya agar warga bisa bermain sepuasnya.

Kedua, hasil dari permainan remi maupun koa itu diberikan kepada keluarga anak yang melakukan sunatan. Bagi yang menang pemain memberikan hasil taruhann semaunya saja. Jumlah uang pertaruhkan oleh pemain paling rendah Rp.10.000., dan paling tinggi Rp.30.000. Pemain yang menang dalam satu labuan bisa memberikan $50 \%$ untuk anak yang sunat $50 \%$ lagi untuk pemain. $50 \%$ yang diberikan oleh pemain tergantung kepada berapa jumlah taruhan yang dimainkan. Jika pemain mendapatkan Rp.120.000., maka pemain bisa memberikan kepada tuan rumah sekitar Rp.60.000., atau lebih. Bertolak dari penelitian di atas, maka peneliti tertarik meneliti secara khusus mengenai judi terselubung di balik momen budaya dan agama yang dikenal dengan Jago Malam dalam Rangkaian Upacara Sunatan di nagari Koto Tuo.

Meskipun secara eksplisit hukum menegaskan bahwa segala bentuk "pertaruhan" khususnya permainan koa dan remi merupakan perbuatan yang melanggar hukum (Pidana \& Kriminologi, 2013), namun dalam masyarakat setempat kegiatan jago malam yang diadakan oleh tuan rumah dilegalkan oleh masyarakat setempat. Penelitian ini bertujuan untuk menggali makna Jago Malam bagi masyarakat Koto Tuo setelah sunatan dan bagaimana masyarakat setempat memandang kegiatan jago malam tersebut. Untuk melengkapi hasil penelitian tentang Jago Malam dalam rangkaian upacara sunatan di Nagari Koto Tuo Kecamatan Sungai Tarab Kabupaten Tanah Datar, peneliti menggunakan teori Interaksionisme Simbolis yang dikembangkan oleh Blumer. Menurut Blumer interaksionisme-simbolis bertumpu pada tiga premis pokok yaitu: (1) manusia bertindak sesuatu berdasarkan kepada makna-makna yang dimiliki benda itu bagi mereka; (2) makna itu berdasarkan hasil interaksi sosial dalam masyarkat; dan, (3) makna-makna tersebut disempurnakan di saat proses interaksi sosial berlangsung (Poloma, 2010).

Peneliti mengabil teori Interaksionisme Simbolis dengan alasan Pertama, Manusia bertindak sesuatu berdasarkan kepada makna-makna yang dimiliki benda itu bagi mereka. Bagi masyarakat Koto Tuo Jago Malam dalam rangkaian kegiatan yang diselenggarakan pada acara sunatan merupakan sesuatu yang bermakna. Mereka memaknai jago malam tersebut sebagai sebuah hiburan ketika malam hari, dan mereka tidak menyebutnya sebagai perjudian, melainkan meramaikan suasana upacara sunatan. Kedua, Makna itu berdasarkan dari hasil interaksi sosial dalam masyarakat. Pada masyarakat setempat permaianan dalam jago malam ini pada rangkaian upacara sunatan sudah berlangsung sejak lama dan berlangsung terus menerus. Dari masa ke masa, jago malam pada malam hari setelah sunatan ini sudah terjadi. Masyarakat itu berinteraksi ketika ada acara sunatan, lalu mereka bersepakat untuk bermain pada malam hari, yaitu koa dan remi yang mereka sebut "Jago Malam". Ketiga, Makna-makna tersebut disempurnakan di saat proses interaksi sosial berlangsung. Masyarakat Koto Tuo berinteraksi dengan melakukan permainan dalam rumah, bahkan bisa juga di halaman tuan rumah yang menyediakan akses permainan tersebut. Rangkaian kegiatan jago malam ini juga sempurna dengan ramainya pemain yang datang, sehingga membuat tali silaturahmi antara pemain yang datang menjadi semakin erat.

Menurut Geoffrey Leech (1981:8), makna dapat dipelajari sebagai fenomena linguistik itu sendiri, bukan sebagai sesuatu di luar Bahasa. Tetapi, cakupan linguistik yang mengkaji tentang makna tidak hanya terdiri dari satu bidang ilmu saja (Chasandra, 1394). Makna yang dibahas oleh penulis ialah makna yang terkait dengan rangkaian upacara sunatan. Dalam rangkaian upacara sunatan ada kegiatan hiburan malam berupa permainan remi maupun koa, orgen tunggal atau

\section{Culture \& Society: Journal of Anthropological Research Vol. 1, No. 1, Th. 2019}


"saluang". Kegiatan hiburan malam inilah yang dimaknai oleh masyarakat setempat sebagai jago malam.

Upacara tradisional memiliki fungsi dalam mengokohkan nilai-nilai dan norma yang berlaku di tengah masyarakat. Salah satu bentuk bentuk upacara tradisional Minangkabau adalah tradisi sunatan massal yang diadakan sekali setahun. Upacara ini patut diteliti dalam rangka menghargai budaya dan mempertahankan identitas diri bangsa serta upaya membangun karakter anak (Wirdanengsih, 2016).

\section{Metode Penelitian}

Penelitian ini dilakukan di Nagari Koto Tuo Kecamatan Sungai Tarab Kabupaten Tanah Datar. Penelitian ini termasuk kualitatif dengan tipe studi kasus. Pendekatan kualitatif dipilih dengan pertimbangan untuk mendapatkan data yang mendalam, suatu data yang mengandung makna (Meleong, 2005). Penelitian kualitatif biasanya menghasilkan data deskripsi berupa katakata tertulis atau lisan dari orang-orang dan perilaku yang diamati. Melalui penelitian kualitatif penulis mendapat informasi berupa ungkapan dan penuturan langsung (sugiyono, 2007). Teknik pemilihan informan peneliti adalah purposive sampling (Herdiansyah Haris, 2014 ). Berdasarkan kriteria informan yang telah ditetapkan maka informan penelitian adalah: (1) unsur pemerintahan nagari yang berjumlah satu orang; (2) elit tradisinal seperti Niniak Mamak, Alim Ulama dan Cadiak Pandai berjumlah lima orang; (3) warga setempat berjumlah tiga orang; (4) Tuan rumah yang menyediakan fasilitas permainan berkumlah tiga orang; (5) Para pemain berjumlah tiga orang; (6) Polisi satu orang, dengan jumlah informan keseluruhan ialah 16 orang.

Teknik pengumpulan data yang digunakan adalah wawancara, observasi, dan studi dokumentasi. Berkaitan dengan observasi ini, peneliti menggunakan metode non partisipasi (non participation), yaitu suatu bentuk observasi di mana peneliti tidak terlibat langsung dalam kegiatan kelompok, atau dapat juga dikatakan peneliti tidak ikut serta dalam kegiatan yang diamatinya (A Muri Yusuf, 2014).

Observasi yang dilakukan adalah observasi non partisipatif, maksudnya peneliti hanya sekedar melihat bagaimana proses dalam rangkaian kegiatan jago malamnya. Wawancara yang yang digunakan dalam penelitian ini adalah wawancara mendalam (indepth interview). Ketika melakukan wawancara peneliti mengajukan pertanyaan berdasarkan pertanyaan yang dikembangkan dari pedoman wawancara.

Studi dokumentasi dilakukan sebagai upaya untuk melengkapi dan memperkuat data wawancara dan observasi. Data yang tidak bisa didapatkan secara rinci melalui teknik wawancara dan observasi, bisa didapatkan melalui studi dokumentasi atau arsip-arsip. Data yang penulis ambil dari dokumen atau arsip seperti, arak-arakan keliling kampung, jumlah anak yang sunatan, jumlah tuan rumah yang menyedikan fasilitas permainan. Agar data yang diperoleh menjadi terpecaya, maka dilakukan tringulasi data. Jenis triangulasi yang dipakai pada penelitian ini yaitu triangulasi sumber.

Analisa data yang dilakukan oleh peneliti menggunakan analisa data yang mengacu pada model analisa interaktif (interactive analytis) dikembangkan oleh Miles dan Huberman (Silalahi, 2009). Model analisis interaktif menurut Miles Huberman yaitu dalam penelitian kualitatif memungkinkan dilakukan analisis data ketika peneliti berada di lapangan ataupun sesudah kembali dari lapangan baru diadakan analisis. Dalam penelitian ini analisis data telah dilakukan bersamaan dengan proses pengumpulan data. Dalam penelitian proses analisis ini dilakukan melalui tahap pengumpulan data, reduksi data, penyajian data, penarikan kesimpulan. 


\section{Hasil dan Pembahasan}

\section{Jago Malam dalam Rangkaian Upacara Sunatan}

Pada bagian ini dikemukakan bahasan hasil penelitian tentang Jago Malam dalam Rangkaian Upacara Sunatan di Nagari Koto Tuo Kabupaten Tanah Datar. Peneliti melihat Makna dari kegiatan jago malam yang disediakan oleh tuan rumah.

\section{Kegiatan Jago Malam}

Pelaksanaan kegiatan Jago malam pada masyarakat Koto Tuo dilakukan ketika adanya rangkaian upacara sunatan. Kegiatan ini dilakukan malam hari setelah anak dari tuan rumah disunat terlebih dahulu. Kegiatan ini dilaksanakan dari pukul 23.00 WIB sampai dengan selesai. Bentuk kegiatan jago malam ini berupa hiburan orgen tunggal maupun "saluang" yang disertai dengan permainan remi dan koa. Selama acara bajago malam, tuan rumah sebagai pemilik hayatan akan memfasilitasi peralatan untuk permainan, seperti; kartu koa/remi, meja, kursi, dan fasilitas bermain lainnya bagi warga laki-laki yang datangdan ingin bermain. Selain itu, bagi tuan rumah yang perempuan akan menyediakan minuman ringan seperti air putih, kopi, dan teh, serta kudapan bagi masyarakat yang ikut bermain atau menonton permainan pada malam itu.

\section{a. Permainan Koa}

Permainan koa dan remi merupakan salah satu permainan tradisional bagi orang Minangkabau. Kartu koa ialah kartu yang bertanda bulatan-bulatan yang menunjukkan nilai angka kartu untuk bermain koa (Accounting.,2017). Permainan ini juga merupakan salah satu permainan yang diadakan oleh masyarakat Koto Tuo ketika adanya rangkaian upacara sunatan. Permainan Koa ialah permainan menyusun kartu koa/ceki, yang dimainkan oleh 4-6 orang pemain dalam satu kelompok (Labuan).

Masing-masing pemain didalam kelompok memegang sebelas kartu koa ditangannya, ditambah satu kartu yang dicabut bergantian dari susunan kartu pada arena permainan atau dari buangan pemain sebelumnya. Permainan dimulai dengan pemain pertama mencabut satu kartu dari susunan kartupada arena permainan, kemudian membuang satu kartu ditangan. Hal ini dilakukan secara bergantian oleh setiap pemain sampai ada pemainyang masuk/sampai dengan memiliki 4 seri kartu yang sama.

Para warga yang ingin bermain dirumah anak yang sunatan ini akan mulai berdatangan dari pukul 21.00 WIB hingga nantinya memulai permainan pukul 23.00 WIB sampai selesai. Pemain yang datang untuk bermain akan dibagi menjadi beberapa kelompok. Setiap kelompok permainan koa/remi dinamakan oleh warga setempat dengan sebutan Labuan. Jika yang datang delapan orang pemain yang ingin bermain dirumah anak yang sunatan maka pemain akan dibagi menjadi dua labuan yang masing-masingnya berisikan empat pemain

Permainan koa yang dimainkan dalam satu labuan bisa dimainkan sistem individual atau berpasangan (bermandan) tergantung dengan keinginan para pemain. Permainan dinyatakan selesai apabila ada salah satu pemain yangtelah memenangi permainan sebanyak 3 kali putaranatau biasa disebut tiga kali sampai oleh para pemain. Permainan koa dalam acara bajago malam tidak memiliki ketua dalam satu labuan.

Permainan ini dimainkan didalam rumah anak yang sunatan dan ada juga yang bermain dihalam rumah mereka. Tergantung berapa banyak fasilitas permainan, seperti kartu untuk bermain, berapa banyak meja yang disediakan tuan rumah. Permainan ini diadakan oleh tuan rumah yang anaknya sunatan bertujuan untuk meramaikan rumah mereka, agar anaknya senang melihat banyak orang dirumahnya.

Bagi para pemain koa yang datang, kegiatan bajago malam tidak hanya bertujuan untuk meramaikan rumah anak yang sunatan saja. Beberapa masyarakat yang datang justru bertujuan untuk memuaskan hobby bermain koa. Selain itu, kegiatan bajago malamini juga dijadikan moment untuk berjumpa dengan teman-teman lama. Permainan koa dalam kegiatan bajago malam di Koto Tuo, sebagai suatu kebudayaan ternyata juga diisidengan hal negatif oleh. Hal ini

Culture \& Society: Journal of Anthropological Research Vol. 1, No. 1, Th. 2019 
dikarenakan permanian koa yang dilakukan oleh masyarakat saat kegiatan bajago malam disisipkan dengan taruhan uang. Walaupun berdasarkan pengakuan pemain taruhan dilakukan masih kecil antara Rp. 5.000 - Rp. 30.000.

Fenomena taruhan dalam permainan koa saat bajago malam sebenarnya bukanlah budaya asli dari bajago malam. Kegiatan taruhan tersebut hanya ditambahkan oleh para pemain yang ingin mendapatkan keuntungan.

\section{b. Permainan Remi}

Permainan remi yang diadakan oleh tuan rumah sama dengan permainan koa. Bedanya permainan remi ini dinamakan oleh warga setempat yaitu permainan Joker Banting karena didalam kartu yang dimainkan oleh pemain terdapat empat joker dan kartu joker ini diambil oleh pemain secara acak. Aturan permainanya sama dengan permainan koa disetiap kelompok memiliki empat orang pemain. Bedanya jika permainan koa menentukan pemenangnya tiga kali sampai atau tiga kali putaran baru dikatakan menang tetapi, permainan remi ini hanya satu kali putaran saja sudah dikatakan menang dalam satu kelompok.

Lebih banyak yang terlihat itu ialalah permainan koa. Hanya pada tahun 2018 beberapa dari tuan rumah yang menyediakan permainan remi ini. Pada tahun 2019 ini tidak ada satupun dari tuan rumah yang menyediakan kartu remi.

\section{c. Orgen Tunggal dan Saluang}

Kegiatan hiburan malam lainnya yang dilaksanakan oleh masyarakaat setempat, yaitu orgen tunggal dan saluang. Tergantung tuan rumah menyediakan hiburan malam yang mana, bisa berupa orgen tunggal maupun saluang. Hiburan malam ini bertujuan menarik perhatian warga setempat untuk beramai-ramai ke rumah anak yang sunatan dan menghibur masyarakat Koto Tuo. Tuan rumah memulai acara dengan hiburan orgen tunggal dari pukul 21.00 WIB sampai pukul 02.00 WIB. Para pemain akan mulai berdatangan dari pukul 21.30 WIB sampai nantinya memulai permainan pukul $23.00 \mathrm{WIB}$ sampai sebelum adzan subuh.

Kenyataan kegiatan bajago malam pakai orgen tunggal ini juga memberi efek kurang enak bagi sebagain masyarakat sekitar tempat acara. Banyak dari warga yang mengeluh terhadap kegiatan jago malam ini, terutama bagi ibu-ibu pada masyarakat Koto Tuo. Pihak pemerintahan nagari juga sudah pernah memberikan peraturan secara tertulis agar ditiadakannya permainan ketika kegiatan jago malam, tetapi hanya sebagian orang yang mendengarkan dan mangikuti peraturan tersebut. Karena sudah menjadi kebiasaan bagi masyarakat Koto Tuo mengadakan kegiatan jago malam tersebut. Jadi, sangat sulit menghilangkan kegiatan permainan koa maupun remi ketika diadakannya hiburan malam berupa orgen tunggal tersebut.

banyak dari warga setempat yang terganggu dengan diadakannya permainan dalam kegiatan Jago Malam ini. Tetapi kegiatan permainan koa maupun remi pada malam hari sudah menjadi kebiasaan ketika adanya rangkaian upacara sunatan. Kegiatan jago malam ini sudah berlangsung sejak lama, dari tahun ke tahun kegiatan ini ada. Para pemain berinteraksi ketika diadakannya acara sunatan, lalu mereka bersepakat untuk bermain pada malam hari yaitu permainan koa ataupun remi yang mereka sebut sebagai jago malam.

\section{Judi Terselubung dalam Rangkaian Upacara Sunatan}

a. Munculnya Taruhan dalam Permainan Jago malam

Pemahaman masyarakat Koto Tuo terutama para pemain, seolah-olah pertaruhan yang dilakukan dalam kegiatan permainan koa maupun remi ini pada malam hari, merupakan sumber untuk mendapatkan sesuatu yang di inginkan. Mereka bisa mendapatkan sesuatu tanpa banyaknya usaha yang dilakukan, dengan alasan para pemain melakukan pertaruhan tersebut untuk menjaga anak yang selesai disunat. Ditambah lagi dengan adanya hiburan malam seperti orgen tunggal maupun saluang membuat para pemain lebih terdorong untuk melakukan permainan yang berujung pertaruhan.

\section{Culture \& Society: Journal of Anthropological Research Vol. 1, No. 1, Th. 2019}


Banyak dari pemain yang memanfaatkan kegiatan yang dilakukan sekali setahun untuk memperoleh keuntungan dan menyalurkan kebiasaan mereka yang suka untuk bertaruh. Dengan adanya fasilitas yang disediakan oleh tuan rumah membuat para pemain yang candu dalam permainan ini terdorong untuk bermain di rumah anak yang sunatan. Walaupun alasan mereka bermain untuk menjaga anak yang sunatan tetapi mereka memanfaatkan ini untuk kepentingan mereka sendiri. Apalagi kegiatan jago malam ini sudah menjadi rangakaian dalam upacara sunatan sehingga para pemain tidak canggung lagi dalam bermain. Pemain bebas bermain tanpa ada rasa takut untuk di tangkap pihak hukum. Hampir setiap rumah yang anaknya sunatan mengadakan kegiatan Jago malam. Tercatat pada tahun 2019 ada 15 rumah yang menyediakan fasilitas permainan ini maka, para pemain yang candu bermain mereka akan mendatangi setiap rumah yang menyediakan fasilitas itu untuk memuaskan diri dan mendapatkan keuntungan bagi diri sendiri. Apalagi pecandu ini ialah salah satu dari tuan rumah yang menyediakan fasilitas permainan dalam kegiatan jago malam maka mereka akan lebih banyak menyediakan fasilitas permainan sehingga mereka puas dengan bermain karena mereka akan memanfaatkan kesempatan ini untuk bermain dan bertaruh sepuasnya.

\section{b. Hasil dari Permainan}

Hasil taruhan yang ditaruhkan pada saat bermain oleh para pemain diberikan kepada anak yang sunat di atas rumah yang mengadakan kegiatan jago malam tersebut. Para pemenang disetiap labuan akan memberikan setengah dari hasil taruhannya kepada anak dari tuan rumah. Jumlah yang diberikan tergantung pada pemain yang menang, bisa setengah dari yang didapatkan atau bisa lebih.

Tetapi dari yang penulis lihat tidak semua pemberian yang diberikan oleh pemain diterima oleh tuan rumah yang menyediakan fasilitas permainan tersebut. Beberapa dari orang tua anak yang sunatan tidak menerima hasil taruhan yang dimenangkan oleh para pemain. Terdata pada tahun 2019 ada lima rumah yang tidak menerima pemberian dari pemain yang diberika kepada anak mereka. tetapi pemain yang tidak diterima pemberian uangnya kepada anak tersebut akan memberikan hasilnya kepada ayah dari anak yang sunatan itu.

Terbukti pada tahun 2019 ini ada lima orang tua yang sunatan tidak menerimi uang dari hasil permainan tersebut. Sehingga makna yang di pakai dan disempurnakan sebagai instrumen bagi pengarahan dan pembentukan tindakan bagi masyarakat setempat berbeda. Mereka memaknai permainan itu berbeda-beda, ada yang menerima hasil permainan dengan baik dan ada yang sama sekali memandang hasil dari permainan itu tidak baik. Tergantung kepada bagaimana masyarakat setempat memaknai permainan ini. Banyak dari orang tua mereka beranggapan bahwa taruhan tersebut tidak baik sehingga uang yang didapatkan tidak baik diberikan kepada anak yang sunatan.

\section{Kesimpulan}

Berdasarkan hasil penelitian dapat ditarik kesimpulan sebagai berikut; (1) Jago malam salah satu kegiatan dalam rangkaian upacara sunatan di nagari Koto Tuo. Kegiatan ini dilakukan sekali setahun dan jago malam ini dimulai pada malam hari setelah anak dari tuan rumah sudah disunat terlebih dahulu. Kegiatan ini akan diiringi dengan permainan koa maupun remi, dan hiburan malam berupa orgen tunggal maupun saluang ikut serta dalam rangkaian kegiatan jago malam tersebut. Permainan ini akan dimulai dari pukul 23.00 sampai sebelum adzan subuh dan dimulai dengan hiburan malam terlebih dahulu berupa orgen tunggal maupun saluang; (2). Permainan yang dilakukan oleh warga yang ingin bermain difasilitasi oleh tuan rumah yang mengadakan acara hiburan malam tersebut. Fasilitas yang disediakan oleh tuan rumah berupa tempat bermain, kartu remi ataupun koa dan makanan untuk para tamu dan pemain. Para pemain yang ingin bermain akan dibagi beberapa kelompok tergantung berapa pemain yang ingin bermain. Kelompok dalam permainan itu disebut oleh warga setempat ialah Labuan. Isi dalam satu labuan

Culture \& Society: Journal of Anthropological Research Vol. 1, No. 1, Th. 2019 
bisa berbeda tergantung berapa pemain yang datang untuk bermain di rumah anak yang sunatan tersebut. Permainan ini tidak memiliki ketua dalam satu labuan, permainan ini selesai dan pemain dikatakan menang ketika sudah melewati tiga kali putaran atau bisa disebut tiga kali sampai oleh para pemain. Setelah melewati tiga kali putaran baru bisa dikatakan pemain tersebut menang. Dalam satu labuan pemain bisa bermain individual atau bisa juga dua lawan dua tergantung kesepakatan bersama; (3). Adanya judi terselubung dalam rangkaian upacara sunatan yang dibalut dengan nuansa budaya yang ada dalam kegiatan upacara sunatan di nagari Koto Tuo. Uang yang didapat dari hasil bermain oleh pemain akan diberikan 50\% kepada anak yang sunatan.

\section{Daftar Pustaka}

A Muri Yusuf. (2014). Metode Penelitian Kuantitaif, Kualitatif \& Penelitian Gabungan. jakarta.

Accounting, D., Cards, D., Accounting, A. S., On, M., Adjusting, T. H. E., Section, E., ... Of, S. (2017). Pengembangan Kartu Domino Akuntansi Sebagai Media Penyesuaian Dalam Meningkatkan Prestasi Belajar Akuntansi Siswa Kelas Xii Ips Sma Negeri 1 Pengasih Tahun Ajaran 2016 / 2017. $21,1-17$.

Cahyono, A. (2006). Seni Pertunjukan Arak-Arakan Dalam Upacara Tradisional. Harmonial Jurnal Pengetahuan Dan Pemikiran Seni.

Editor, T. (n.d.). No Title.

Gibran, M. K. (2015). Tradisi Tabuik di Kota Pariaman. Jurnal Jom Fisip.

Herdiansyah Haris. (2014). metode penelitian kualitatif(Salemba Hu). jakarta.

Lahengko M. Chasandra. (1394). jenis makna dalam the book of proverbs.

Panjaitan, J., \& Bayu, I. M. (2018). Respon Masyarakat Lokal Terhadap Aktivitas Hiburan Malam Di Legian, Kuta. 6(1), 199-203.

Pertunjukan Kesenian Pantun Rajah Grup Gentra Pusaka Panca Tunggal Dalam Acara Ngarut Anak Tunggal Di lebak Mekar Kabupaten Cirebon. (2013). Swara: Jurnal Antologi Departemen Pendidikan Seni Musik FPSD UPI.

Pidana, H., \& Kriminologi, D. A. N. (2013). Skripsi budaya sabung ayam dalam perspektif hukum pidana dan kriminologi.

Poloma, M. (2010). sosiologi kontemporer.

Sa, N. A.-, Dalam, A., Dan, P., Khitan, P., \& Perempuan, B. (1996). Ditinjau Dari Kesehatan Dan Islam Fuad Mahbub Siraj.

Silalahi, U. (2009). Metode Penelitian Sosial. bandung.

Sugiyono. (2007). Metode Penelitian Kuantitatif, Kualitatif dan R\&D.

Wirdanengsih, W. (2016). Tradisi “ Mandoa” Untuk Anak Khatam Quran Dalam Keluarga Luas Minangkabau ( Studi Etnografi, Tradis Mandoa Anak Berkhatam Quran Di Tigo Baleh Bukit Tinggi Sumatera Barat). Jurnal Harkat: Media Komunikasi Gender, 12(1), 83. https://doi.org/10.15408/harkat.v12i1.7583 